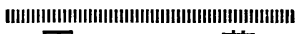 \\ 家 \\ ………1 \\ 新しく開発した螢光ガラス線量計による \\ 低線量測定とエネルギー依存性
}

\author{
横田良助, 中島三郎, 上杉泰男
}

（東芝中央研究所）

(昭和 36 年 7 月 17 日 受理)

\section{緒言}

（1）個人被曝監視用として， $\gamma$ 線に対して 30 $\mathrm{mr}$ より $3000 \mathrm{mr}$ (事故時に備えて) まで測定でき, 線量率, 方向に依存せず, fading が無視できて, 13 週間にわたって積算可能であり, 簡便に測定で きるものが要望されている。

放射性同位元素を扱う人に対しては手に $\beta$ 線が 被曝することがあり，同様に $100 \mathrm{mrad} よ り 3000$ mrad まで測定できることが要望される。

深部線量分布を細かく測定するには寸法の小さ い直径 $1 \mathrm{~mm}$, 長さ $6 \mathrm{~mm}$ の䖝光ガラス棒がとく に適している。また䖝光ガラスは人体内に挿入す ることによって内部被曝が測定できる可能性が生 ビた。

われわれが開発した䖝光ガラス線量計は以上の 目的にとくに適したものである。

(2) radiophotoluminescence と銀活性リン酸 ガラス

固体(誘電体)が放射線に懪されると, 安定な䖝 光中心が生成する。すなわち, 紫外線または可視 光線の刺激で䖝光中心は䖝光を発する。この現象 を radiophotoluminescence といい，被曝量と 螢光強度とは比例関倸にある。

この現象を示す物質としてよく研究されている のは $\mathrm{Ag}$ がわずかにはいった $\mathrm{NaCl}(\mathrm{Ag})$ である1)。 この物質は被曝前においては $365 \mathrm{~m} \mu$ 刺激で螢
光を発しないが, 被曝後は $365 \mathrm{~m} \mu$ 刺激で黄色の 螢光を発する。この現象を線量計として利用する には $\mathrm{NaCl}(\mathrm{Ag})$ は生成条件に敏感にすぎて一定 のものを作りにくい。

Weyl, Schulman ら² は銀を含んだアルカリア ルミノリン酸塩ガラスが radiophotoluminescence を示すことを見出し, Schulman ら³が線量 計として応用した。実施されたガラス組成は $\mathrm{KPO}_{3} 25, \mathrm{Ba}\left(\mathrm{PO}_{3}\right)_{2} 25, \mathrm{Al}\left(\mathrm{PO}_{3}\right)_{3} 50$ (wt\%) の基 体ガラスに $\mathrm{AgPO}_{3} 8 \mathrm{wt} \%$ 導入されたものであ る。

被曝後 $365 \mathrm{~m} \mu$ 刺激で橙色の䖝光を発する。こ の螢光中心は通常いわれているような原子状銀 一 $\mathrm{Ag}^{\circ}\left(\mathrm{Ag}^{+}\right.$イオンに電子が捕獲されたもの) ではなくて, $\mathrm{Ag}^{+}$イオンとそれに隣る正イオン空 孔に正孔が捕獲されたものであると考えられる。

また被曝前でも近紫外線刺激で弱いが䖝光が生 ずる。それは $\mathrm{Ag}^{+}$イオンによるものと通常考え られているが，著者らは，不純物によるものや $\mathrm{Ag}^{+}$イオンの複合したものによるものからなり たっていると考える。

Schulman らが開発したガラスおよび測定器で は被曝前䖝光量が $~ 30 \mathrm{r}$ 相当分あるので $2 \mathrm{r}$

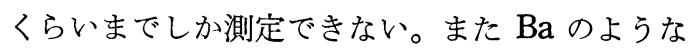
原子量の大きな元素を多量に含んでいるのでエネ ルギー依存性が大きい欠点がある。

われわれは $\mathrm{K}, \mathrm{Ba}$ を含まず， $\mathrm{Li}, \mathrm{B}$ を含む銀 
活性リン酸ガラスで被曝前の䖝光を著しく小さく することに成功した文。その組成は $\mathrm{LiPO}_{3} 50$, $\mathrm{Al}\left(\mathrm{PO}_{3}\right)_{3} \quad 50$ (wt\%) の基体ガラスに $\mathrm{B}_{2} \mathrm{O}_{3} \quad 3 \%$, $\mathrm{AgPO}_{3} 7 \%(\mathrm{wt})$ 導入したものである4)。

\section{1. 線量計としての銀活性リン酸ガラス}

（1）低線量測定用螢光線量計ガラスの性能の表 現

われわれが開発したガラスを FD-1 と呼び， Schulman が開発したものを FD-2 と呼ぶこと にする。

FD-1 の被曝前の吸収, 被曝後の吸収および，

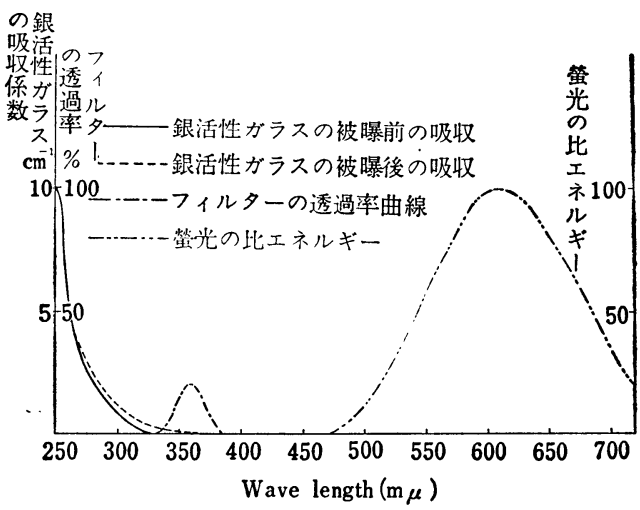

Fig. 1 Absorption and luminescence spectrum in silver-activated phosphate glass FD-1

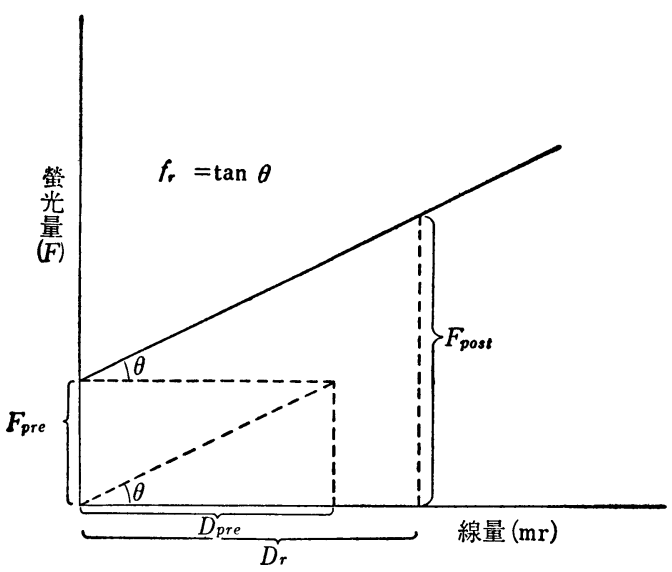

Fig. 2 Characteristic diagram of fluorodosimeter glass at low dose range
$365 \mathrm{~m} \mu$ 近傍透過フィルターの透過率曲線を Fig. 1 に示す。被曝後 $365 \mathrm{~m} \mu$ で刺激したとき発生す る螢光のエネルギー分布を同図に示す。䖝光は赤 フィルターを通して $\mathrm{Ag}-\mathrm{Bi}-\mathrm{Cs}$ 光電面を持つ光 電子増倍管でうけて光電流として測定する。Fig. 2 に FD-1 ガラスの特性を図式的に示す。

FD-1 では低線量域 ( 10 mr) まで直線的であ るが FD-2 などではかならずしもそうではない。

FD-1 が被曝 $\gamma$ 線より吸収したエネルギー（吸 収線量）を $D_{r}$ とし，単位吸収線量に対する䖝光 ガラスの䖝光量増加分を $f_{r}$ とする。FD-1 は被 曝前にも罃光を発する。その䖝光量を $F_{p r e}$ とす る。すると $D_{r}$ 吸収後のガラスの䖝光量 $F_{p o s t}$ は

$$
F_{p o s t}=F_{p r e}+f_{r} D_{r}
$$

FD-1 の $S / N$ は

$$
S / N=f_{r} / F_{\text {pre }}
$$

である。

predose とは $F_{\text {pre }}$ を線量に換算したものであ って Fig. 2 の $D_{\text {pre }}$ であるから

$$
D_{\text {pre }}=F_{\text {pre }} / f_{r}=1 /(S / N)
$$

いま $D_{\text {pre }}$ が $300 \mathrm{mr}$ であればその $1 / 10=30$ $\mathrm{mr}$ は $\pm 10 \%$ の精度で測定できる。 $D_{\text {pre }}$ が小さ ければ小さいほど低線量が測定できる。

FD-1 と FD-2 とでは $f_{r}$ は同一であるが $F_{p r e}$ は前者の方が小さい。

従来米国で作られている FD-2 は predose $\left(D_{p r e}\right)$ が 30r であり，また 3〜20r 範囲では $f_{r}$ が減少していたので $5 \mathrm{r}$ までしか測定できない。

$f_{r}$ は $\pm 2 \%$ 以内で一定にできるが， $F_{\text {pre }}$ は種 種の理由で一定でなく る。したがって測定はまず $F_{p r e}$ を測定し，つぎ に $F_{p o s t}$ を測定し, $F_{p o s t}-F_{p r e}$ を求めてこれを レスポンスとする。

すべての FD-1 のレスポンス対線量は 1 本の直 線で表わされる。

（2）直線性と加算可能性

前述したように FD-1 のレスポンス対線量は直 線的であるが，これは自明のことではない。従来 の米国の FD-2 では $3 \sim 20 \mathrm{r}$ 範囲では $f_{\gamma}$ が 20 
横田，中島，上杉：新しく開発した螢光ガラス線量計による低線量測定とェネルギー依存性

$\mathrm{r}$ 以上の $f_{r}$ と異なっていた。

われわれは，predose を著しく小さくし，570 $\mathrm{m} \mu$ より長い波長の螢光のみを通すフィルターを 光電子増倍管の前におくことによって，レスポン スは 10 mr より $3000 \mathrm{r}$ までまったく直線的で あることを見出した4)。

この直線性と後述する䖝光中心が安定であるこ とより加算可能である。したがって週ごとの被曝 線量を求めうると同時に, 13 週間の累積被曝線量 も求めうる。

ただし，累積被曝線量が大きくなると predose が大きいのと同じことであるから低線量測定の精 度が低下し，ついには測定できなくなる。

(3) 方向依存性

FD-P 8-1 および FD-P 6-1 のガラスはその形 状よりして裸のままでも方向依存性がほとんどな い。Sn $1.0 \mathrm{mmt}$ ，または黄銅 $1.0 \mathrm{mmt}$ でガラス 全面をカバーしても同様である(Table 1 参照)。 黄銅 $1.0 \mathrm{mmt}$ カバーは指輪状のものについて行 なったものである。方向依存性がほとんどないこ とが大きな特徴である。

Table 1

\begin{tabular}{|c|c|c|c|}
\hline & $\begin{array}{c}\text { FD-P 8-1 } \\
\text { はだか } \\
49 \mathrm{kV}_{\text {eff }}\end{array}$ & $\begin{array}{c}\text { FD-P 8-1 } \\
\text { Sn 1.0 mmt } \\
\text { シ- F゙ } \\
60 \mathrm{Co} r \text { 線 }\end{array}$ & $\begin{array}{c}\text { FD-P 6-1 } \\
\text { 黄銅 1.0 mmt } \\
\text { シ - F゙ } \\
60 \text { Co } r \text { 線 }\end{array}$ \\
\hline $0^{\circ}$ & 1.00 & 1.00 & 1.00 \\
\hline $30^{\circ}$ & 1.03 & 1.04 & 0.93 \\
\hline $45^{\circ}$ & 1.05 & 1.06 & 0.95 \\
\hline $60^{\circ}$ & 1.06 & 1.08 & 0.98 \\
\hline $90^{\circ}$ & 1.03 & 1.05 & 1.15 \\
\hline
\end{tabular}

ここで $8 \times 8 \mathrm{~mm}^{2}, 6 \times 6 \mathrm{~mm}^{2}$ の面への垂直入 射の場合を $0^{\circ}$ とする。

(4) fading

放射線によって生じた螢光中心はきわめて安定 である。 $\gamma$ 線を $300 \mathrm{mr}$ 被曝したのち室温に保持 しておいた場合, 13 週間後における fading(螢 光中心の数の減少) は FD-P 8-1 では 3\%, Sch- ulman ガラスでは $6 \%$ であった。保存状態はとく に暗所に保存したわけではなく, 紫外線に曝され ない状態である。螢光測定時には測定器光源の紫 外線に曝されるが短時間であるので影響はない。

ただし以上は自然放射線による影響は無視し た。

（5）線量率依存性

$0.1 \mathrm{mr} / \mathrm{min} \sim 100 \mathrm{r} / \mathrm{min}$ の広い範囲の線量率 の変化に対して全積算線量は線量率に依存しな い。

(6) 温度効果

䖝光測定時の温度係数は $-0.7 \% /{ }^{\circ} \mathrm{C}$ であるが， ほとんど温度係数の等しい Mn または Sm ガラ ス（螢光の色は赤）を標準に用いることによって 相殺することができる。

被曝後保存時の温度が $4 \sim 35^{\circ} \mathrm{C}$ ならば保存温 度の影響は無視できる。

被曝時の温度効果は $55^{\circ} \mathrm{C}$ 以下では $+0.2 \% /{ }^{\circ} \mathrm{C}$ である。身体装着時の温度は $5 \sim 35^{\circ} \mathrm{C}$ であるか ら，この温度範囲で被曝するときはほとんど無視 できる。

䖝光線量計ガラス FD-1 は被曝直後の䖝光量は 終局值の約 $70 \%$ であって $30^{\circ} \mathrm{C}$ の場合に 3 時間 で終局值の $98 \%$ に達する。Fig. 3 に $30^{\circ} \mathrm{C}$ に保 存したときの螢光量の build up を示す。 4 時間 で飽和值に達する。被曝後 $100^{\circ} \mathrm{C}$ または $120^{\circ} \mathrm{C}$ で 8 分間加熱し, のち $30^{\circ} \mathrm{C}$ に保存した場合を Fig. 3 に示す。この熱処理により $30^{\circ} \mathrm{C}$ における

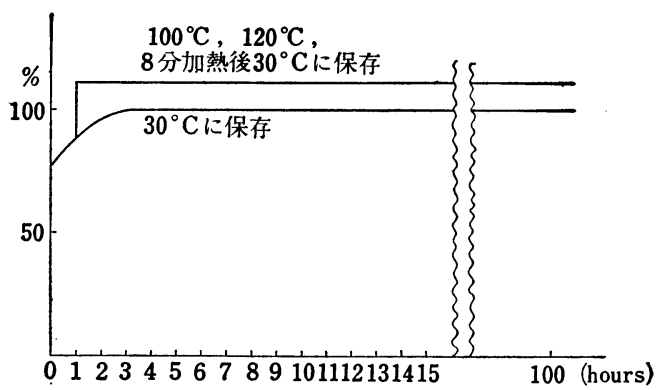

Fig. 3 Variation of luminescence response of exposed FD-1 glass with storage time in the dark 
飽和值の $111 \%$ に達し，以後一定である。したが って補正をすれば, 被曝後ガラスを $100^{\circ} \mathrm{C}$ の蒸 留水で洗うこともできる。

\section{2. エネルギー依存性}

䖝光ガラスのレスポンスはガラスが放射線より 吸収したエネルギーに比例する。narrow beam geometry の下では単位照射線量あたりのガラス の吸収エネルギー $D_{g}$ は電子平衡が成立する条件 の下では

$$
D_{g}=0.87_{7}(\mathrm{~m} \mu)_{g} /(\mathrm{m} \mu)_{a i r} \text { rads }
$$

ここで $(\mathrm{m} \mu)_{g},(\mathrm{~m} \mu)_{a i r}$ はそれぞれガラスおよ び空気の真の質量吸収係数である。 $(\mathrm{m} \mu)_{g}$ 法計算 によって求める。 $1.0 \mathrm{MeV}$ の $\gamma$ 線での值を 1 と したときの計算値を Fig. 4 に示す。

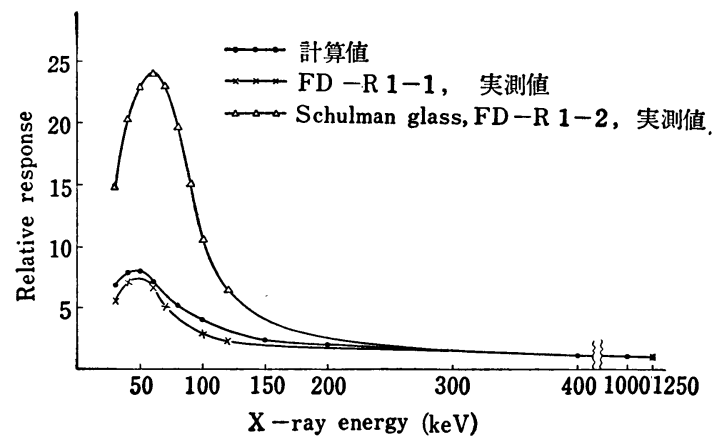

Fig. 4 Energy dependence of FD-1 and FD-2

FD-1 ガラスは原子量の大きな元素を含まない (これを low Z-glass という) から，エネルギー 依存性が小さい。 $1 \mathrm{~mm} \phi \times 6 \mathrm{~mm}$ 棒での実側值 を同時に同図に示す。FD-2 ガラスよりもエネル ギー依存性が著しく減少している。

FD-P 8-1 ではその寸法のためにエネルギー依 存性は単純に (4) 式で表わされるものとはならな いが, Fig. 5 に表わされるものとなり，フィルム バッジ用フィルムの約 $1 / 4$ にエネルギー依存性が 減少している。

Fig. 5 に Sn: 0.5, 1.0, 1.2, $1.5 \mathrm{mmt}$ カバー の場合のエネルギー依存性を示す*。Cd カバーの

* 照射は電気試験所大村技官によって行なわれた。

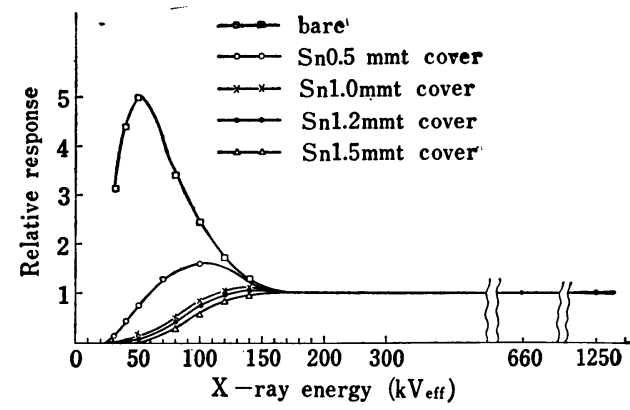

Fig. 5 Energy dependence of FD-P 8-1 (bare, Sn $0.5,1.0,1.2,1.5 \mathrm{mmt}$ cover)

場合は $\mathrm{Sn}$ と同一の值を与える。120 $\mathrm{kV}_{\text {eff }}$ より ${ }^{60} \mathrm{Co} \gamma$ 線までのエネルギー範囲では Sn $1.2 \mathrm{mmt}$ をカバーすることにより $\pm 5 \%$ の範囲でエネルギ 一に依存しない。なお裸のときと Sn カバーのと きと $\gamma$ 線における感度は同一である。

FD-P 6-1 ガラスはフィルムリングに代るガラ

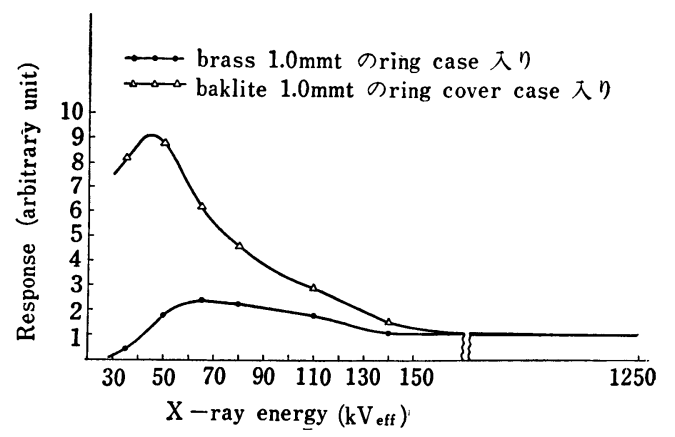

Fig. 6 Energy dependence of FD-P 6-1

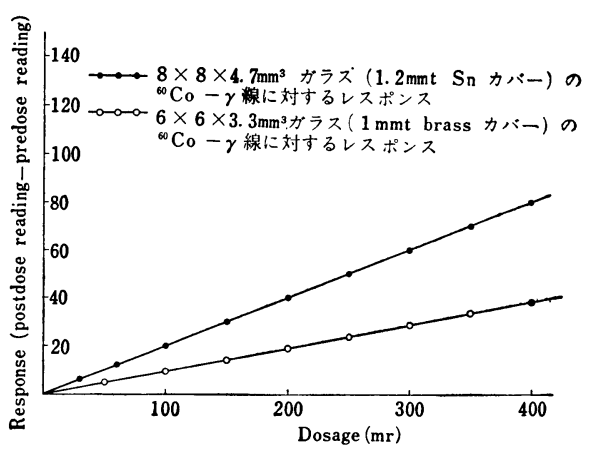

Fig. 7 Response of low dose range in FD-P 8-1 (Sn $1.2 \mathrm{~mm}$ cover) and FD-P 6-1 (brass $1.0 \mathrm{~mm}$ cover) 
横田，中島，上杉：新しく開発した螢光ガラス線量計による低線量測定とェネルギー依存性

スリングとして開発されたものである。1.0 mmt 黄銅がケース兼フィルターとして作用しており (Fig. 6) エネルギー依存性を減少している。

さらに $\mathrm{Pb} 0.3 \mathrm{mmt}$ をガラスにカバーするこ とにより ${ }^{60} \mathrm{Co} \gamma$ 線より $120 \mathrm{kV}_{\text {eff }}$ までのX線に対 してェネルギー依存性はまったくなくなると思わ れる。

\section{3. 螢光量測定器および測定法 ${ }^{5}$}

紫外線光源としては東芝製 100 Watt 超高圧水 銀灯 SHL-100-UV-2 を用いる。これは放電灯で ありながら十分安定なものである。東芝製光電式 定電圧装置によって安定電圧 $100 \pm 0.1 \mathrm{~V}$ で点灯 させる。東芝製フィルターを組み合わせて 365 $\mathrm{m} \mu$ 近傍の紫外線のみをとり出す。紫外線は $8 \times$ $8 \mathrm{~mm}^{2}$ の面, または $6 \times 6 \mathrm{~mm}^{2}$ の面, または 棒の長さの面に対して垂直に入射させ，発生する 䖝光を紫外線と垂直方向から赤に感度の大きい $\mathrm{Ag}-\mathrm{Bi}-\mathrm{Cs}$ 光陰極の 10 段の光電子増倍管（東芝 製 PM-50) で測定する。PM-50 の前に散乱紫外 線を遮断すると同時に紫外線で螢光の出ないフィ ルター 2 枚を組み合わせて䖝光中の赤部分のみを 通過させる。PM-50 よりの陽極電流は直流増幅 器で増幅する。増幅器はグリッド電流の小さい電 位計管 5886 を用い，さらに増幅したのち 100\% 近く入力にフィードバックして安定化したもので ある。入力高抵抗はとくに吟味したものを用いて 安定になっている。入力高抵抗の切換えにより 10 倍ずっ，またメーター回路と直列にはいった抵 抗の切換えにより 10 倍に変化できる。

PM-50 は 600〜650 volt．を印加して測定する ときもっとも安定である。PM-50 は感度がわず かであるが時間とともに変化する。これは fatigue が大部分の原因である。翌日には回復する。 fatigue は測定開始直後がもっともはげしいが 3 分くらいでおち着く。

そこで標準䖝光ガラスよりの螢光を測定して出 カメーターの振れがある一定值を示すように PM -50 に印加する電圧を微細に変化させる。また点
灯中の紫外線光源の螢光量減少も同じ方法で補 う。以上の方法で総合感度一定の状態で測定する ことができる。

FD-P 8-1 と FD-P 6-1 では側面が一面砂目研 磨面になっていて黒鉛筆で番号, 矢印などを付記 することができる。これによってガラスの identification ができ, また測定器に対してガラスの 関係位置が定まり，1 回の測定でよい。FD-R1 の場合にはひっくり返して 2 回測定して平均をと る。

ガラスの污れはとくに十分に注意してのぞかね ばならない。まず特級のアセトンにひたし，つぎ に蒸留水にひたし, 最後に特級のエチルアルコー ルまたはメチルアルコールにひたす。ひたす時間 は污れにもよるが通常 0.5 1 分でよい。ソック スレー抽出装置を用いて洗浄するのもよい方法で ある。ついで乾燥する。乾燥はたんに放置してお いてもよいが東芝へアードライヤーで迅速に乾燥 するのがもっともよい。

手のあぶらなどはつけないよらにする。污れが ついたら，アセトンをしませた脱脂綿でこすりと り，つぎに前述した方法で洗浄する。かくすれば ガラスを直接セロテープではりつけて被曝させる ことができる。

\section{4. $\gamma$ 線， $X$ 線に対する測定}

FD-P 8-1 で低線量を測定するには光電子増倍 管に約 $610 \mathrm{~V}$ 印加し, 被曝前螢光が 100 目盛の 出力メーターで 60〜70 目盛ふれるようにする。 この状態で ${ }^{60} \mathrm{Co} \gamma$ 線 $30 \mathrm{mr}$ 被曝分で 4 目盛子れ る。FD-P 6-1 では同じ状態で $50 \mathrm{mr}$ が 4 目盛 に相当する。線量測定は Victoreen の ion chamber (condenser $\gamma$-meter)によった。これは電 気試験所大村技師によって検定された。

同じ状態で測定して FD-P 8-1 は $\gamma$ 線に対して $3000 \mathrm{r}$ まで, FD-P 6-1 は 5000 r まで直線的で ある。

FD-R 1-1 を 1つには電子平衡を成立させるた めに $3 \mathrm{mmt}$ のアクリルケースに入れて ${ }^{60} \mathrm{Co} \gamma$ 


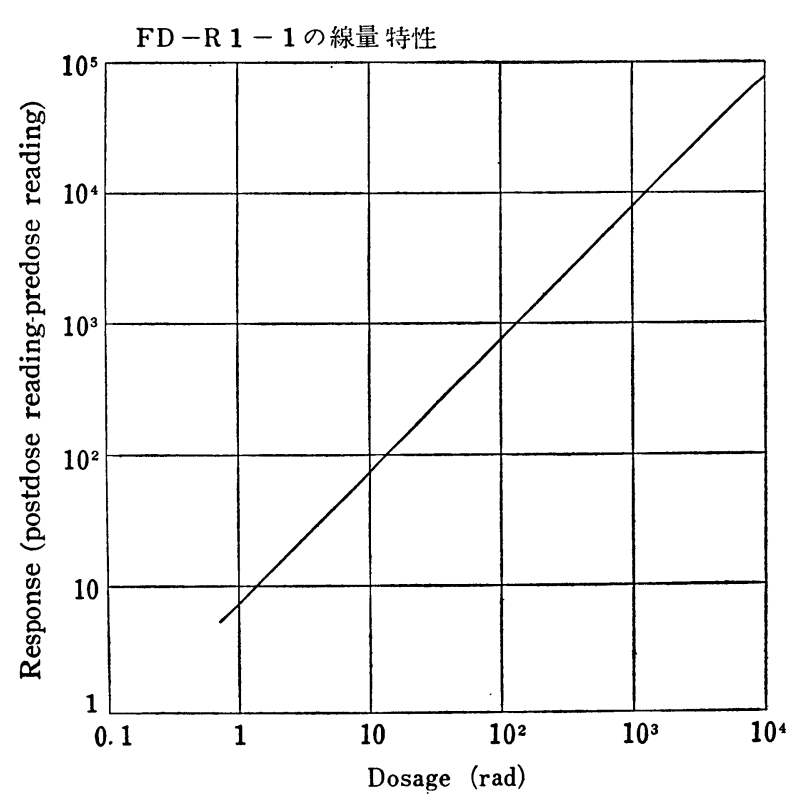

Fig. 8 Response of FD-R1-1

線で照射する。ガラス棒は小さいのでこの影響は 無視できて，ガラス棒のよみはアクリルの吸収線 量を表わす。アクリルは人体軟組織にほぼ相当す る。照射線量を $R(\mathrm{r})$ とすれば $0.12 \sim 3.0 \mathrm{MeV}$ 範 囲では吸収線量は $0.966 R \mathrm{rad}$ となる。Fig. 8 は 横軸に $0.966 R \mathrm{rad}$ をとり縦軸にレスポンスをと ってある。1 $\mathrm{rad}$ から $10^{4} \mathrm{rad}$ まで測定できる。

FD-R 1-1 をファントムや人体中に埋めこんで 実験した場合のガラス棒のよみはただちにファン トムや人体軟組織における吸収線量 (rad) を与え る。

\section{5. $\beta$ 線 の 測定}

$8.43 \mathrm{mc}$ の ${ }^{32} \mathrm{P}$ 水溶液 $100 \mathrm{cc}$ をポリエチレン 製ビーカーにとり，そのほぼ中央にごく細い絹糸 で FD-P 8-1, FD-P 6-1 および FD-R 1-1 をひ たした。一定時間後とり出し, 流水で 1 時間洗っ た。

ガラス面に ${ }^{32} \mathrm{P}$ が残存していないことをガイガ 一計数管で確かめた。照射時間と管光量増加とは まったく直線関係にある。 $\beta$ 線の照射線量 $R_{\beta}$ は

$$
\begin{aligned}
& R_{\beta}=0.0355 \bar{E}_{\beta} c \mathrm{rad} / \mathrm{min} \quad\left(\bar{E}_{\beta} \cdot 0.69 \mathrm{MeV}\right. \\
& =2.14 \mathrm{rads} / \mathrm{min} \quad c=\text { 濃度) }
\end{aligned}
$$
する既知のレスポンスからこれらのガラスの ${ }^{32} \mathrm{P} \beta$ 線に対するレスポンスがつぎのように 求められた。
FD-P 8-1
$0.049 \mathrm{r} / \mathrm{rad}$
FD-P 6-1
$0.086 \mathrm{r} / \mathrm{rad}$
FD-R 1-1
$0.262 \mathrm{r} / \mathrm{rad}$

$\beta$ 線に対する質量吸収係数は一般に物質に あまりよらない。ゆえにガラスの場合でもガ ラスの寸法(厚さ)が小になるほどガラスの吸 収エネルギーに近づく 飛程が短いので寸法(厚さ)が小さいほど厚さ あたりの能率はよくなる。上の結果はこのこ とを示している。

上の結果を用いれば未知の ${ }^{32} \mathrm{P}$ 溶液の濃度 を求めることができる。

\section{6. 螢光ガラス線量計によるファントム内 の線量分布測定}

(a) $200 \mathrm{kVp} \mathrm{X}$ 線照射の場合*

$390 \times 350 \times 350 \mathrm{~mm}^{3}$ の水ファントムの中心軸 にアクリル板をおき，アクリル板にセロテープで FD-R 1-1 をはりつけた。東芝製 $200 \mathrm{kVp}, 20$ $\mathrm{mA}, \mathrm{H} . \mathrm{V} . \mathrm{L} .=2.0 \mathrm{~mm} \mathrm{Cu}$, 照射野 $10 \times 10 \mathrm{~cm}^{2}$ である。Fig. 9 に中心軸の深部線量率特性を示

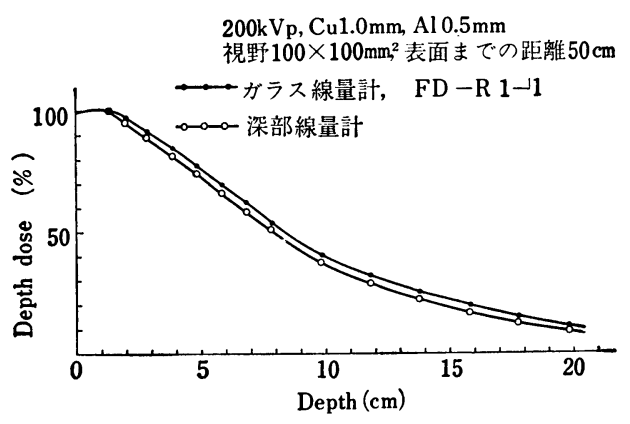

Fig. 9 Depth-dose curve of water-phantom by FD-R1-1, $200 \mathrm{kVp} \mathrm{X-rays}$

* 玉川工場医療放射線技術課と共同で行なったもの。 
横田，中島，上杉：新しく開発した䖝光ガラス線量計による低線量測定とェネルギー依存性

す。同時に電離槽(東芝製深部線量計)による測定 を行なった。その結果は比較的よい一致を示した が，わずかの差が認められた。これはガラスの支 持板による散乱およびガラスの線質依存性による ものが原因であると考えられる。しかし簡単な補 正を行ならことにより実用上差支えないと考えら れる。FD-R 1-1 は外形が微小なるため組織内に 挿入することが可能でさり, 電離槽では測定でき ないことが可能となる。たとえばこれによって表 面より $1 \mathrm{~cm}$ までの深部線量がはじめて求められ たのである。

また線量分布の測定も多数の点を同時に測定し らる。とくに運動照射の場合も 1 回の照射で全分 布を測定することができる。

(b) ベータトロンによるX線および電子線照射 の場合*

$200 \times 200 \times 200 \mathrm{~mm}^{3}$ のゼラチン・ファントム の中心軸の深部線量率を FD-R 1-1 で測定した。 照射視野 $100 \times 100 \mathrm{~mm}^{2}$, ターゲットとファント ム表面までの距離は $70 \mathrm{~cm}$ である。ゼラチン・ ファントムからとり出したガラスはただちに $60^{\circ}$ $\sim 70^{\circ} \mathrm{C}$ の蒸留水でよく洗ってゼラチンをよくお とさなければならない。

東芝製ベータトロン $\mathrm{X}$ 線 $15 \mathrm{MeV}$ および 12 $\mathrm{MeV}$ による哚部線量率を Fig. 10 に示す。

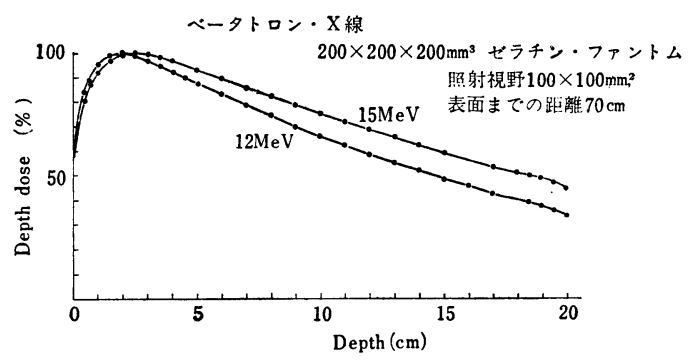

Fig. 10 Depth-dose of gelatin phantom by FD-R1-1; Betatron X-rays

またベータトロンによる $15,10,6 \mathrm{MeV}$ の電子 線の場合の深部線量率を Fig. 11 に示す。

X線および電子線の場合ともとくに表面近くの

\footnotetext{
* 大阪市大藤野教授と共同で行なった。
}

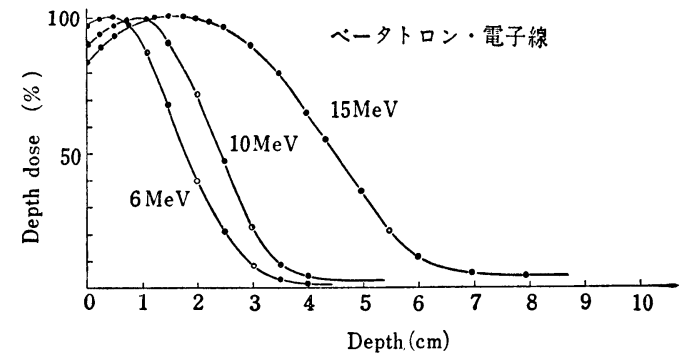

Fig. 11 Depth-dose of gelatin phantom by FD-R1-1; Betatron $\beta$-rays

線量がくわしく求められたことが特徴的である。

\section{7. 結言}

以上のベたようにエネルギー依存性が小さく， fading が無視できて被曝前螢光が著しく小さく, 加工性のよい銀活性ガラスの組成および製造法を 見出すことに成功した。また測定器においても著 しく進歩させて, 低線量域までまったくレスポン スを直線的にすることに成功した。

$8 \times 8 \times 4.7 \mathrm{~mm}^{3}$ の大きさのガラスでは Sn 1.2 $\mathrm{mmt}$ をシールドに用いると ${ }^{60} \mathrm{Co} \gamma$ 線より硬 $\mathrm{X}$ 線 $\left(120 \mathrm{kV}_{\text {eff }}\right)$ までのエネルギー依存性も方向性も無 視できて， $30 \mathrm{mr}$ が $10 \%$ の精度で測定できる ようになり,フィルムバッジの欠点を取り除いた ものとして将来性が大きい。また $6 \times 6 \times 3.3 \mathrm{~mm}^{3}$ のガラスでは $50 \mathrm{mr}$ が測定できてフィルムリン グに代るガラスリングとして用いられる。

また $1 \mathrm{~mm} \phi \times 6 \mathrm{~mm}$ の棒は深部線量や細かい 線量分布を測定するのにとくに適している。

以上の研究は昭和 35 年度原子力平和利用補助 金によって研究したことを付記し，関係各位のご 協力に感謝する次第である。

\section{文献}

1) H. W. Etzel and J. H. Schulman: J.Chem. Phys., 22, 1549 (1954)

2) Weyl, Schulman and Evans: J. Electrochem. Soc., 95, 70 (1949)

3) J. H. Schulman, R. J. Ginther and C.C. Klick: J. 
Appl. Phys., 22, 1479 (1951); J. H. Schulman,

W. Shuscliff, R. J. Ginther and F. H. Attix:

Nucleonics, 11, (10) 52 (1953)

4) 横田, 中島：特許
5）横田良助, 中島三郎, 上杉泰男：第 2 回原子カシ ンポジウムで講演 (昭 36)

6) S. Kondo: Health Physics, 4, 21 (1961)

\title{
Low-level Dose Measurement with Newly Developed Fluoro Glass Dosimeter and the Energy Dependence
}

\author{
By \\ Ryosuke Yokota, Saburo Nakajima and Yasuo Uesugi \\ (Central Research Laboratory, Tokyo Shibaura Electric Co.)
}

(Received July 17, 1961)

New silver-activated phosphate glass which contains large amount of $\mathrm{Li}$ and small amount of B has been developed.

This glass is less energy dependent, and the fading is negligibly small. It can be prepared to be very low predose.

The fluorometer has been developed with many new ideas and the response has become linear from $10 \mathrm{mr}$ up to $3000 \mathrm{r}$ for $\gamma$-rays by the use of low predose glass.
By using the glass of $8 \times 8 \times 4.7 \mathrm{~mm}^{3}$, the integrated dose $30 \mathrm{mr}$ for $\gamma$-rays can be measured with the accuracy of $\pm 10 \%$. This glass is practically independent with the direction of the incident radiation.

By using the glass of $1 \mathrm{~mm} \phi \times 6 \mathrm{~mm}$ length rod, the depth dose measurement and field mapping can be accomplished very conveniently. 